\title{
Assessment of the quality of business education programme in selected higher institutions in Ogun State
}

\author{
Odunaike k. Oluwafemi ${ }^{1}$, Ijaduola Kayode Olu ${ }^{2}$ and Epetimehin F. $\mathbf{M}^{3}$. \\ ${ }^{1}$ Department of Vocational and Technical Education, Tai Solarin University of Education, \\ ljagun, ljebu Ode. Ogun State, Nigeria. E-mail address: odunaikefemi@yahoo.com \\ ${ }^{2}$ Department of Educational Management, Tai Solarin University of Education, ljagun, ljebu \\ Ode, Ogun State, Nigeria. E-mail address: kijaduola07@yahoo.com \\ ${ }^{3}$ Department of Actuarial Science and Insurance, Joseph Ayo Babalola University, Ikeji- \\ arakeji, E-mail address: festusworldwide22@yahoo.com
}

\begin{abstract}
This study assessed the quality of business education programme in selected higher institutions in Ogun State, Nigeria. Thirty (30) lecturers, randomly selected from three higher institutions offering business education participated in the study. A research instrument, developed by the researchers- Quality of Business Education in Higher Institutions Questionnaire (QBEHIQ) was used to collect data. The instrument was subjected to construct validation by two research colleagues while a reliability coefficient $(r=0.87)$ was obtained consequent upon test-retest technique. The study revealed acute shortage of business education teachers, poor funding of the programme; hence the poor state of infrastructural facilities in the institutions. The researchers, therefore recommended among others that governments should fund all programmes in the institutions under their jurisdiction adequately so as to produce competent and marketable graduates.
\end{abstract}

Key words: Quality, Infrastructure, Competency, Commitment, Funding

\section{INTRODUCTION}

Across the global, it has been observed that countries that thrive in all sectors of their economy did embrace education as their bedrock (Meisinger and Wagner (2006). It is therefore not farfetched to understand that a nation is as good as the kind of education system it operates.

For quality of education to be guaranteed, emphasise should be placed on the quality of teaching, in order to ensure impressiveness, efficiency and productivity of education. When focusing on quality, the possibility of national and international level comparability should remain and improve. It is also necessary to control the quality of education by using the relevant agencies such as National University Commission (NUC), National Board for Technical Education (NBTE) as well as National Commission for Colleges of Education (NCCE) etc. These agencies were established in order to ensure the quality of education in Nigeria. The concern here is quality assurance in Business Education.

Business Education is an integral part of vocational and technical education. It is a form of vocational education according to Idialu (2007) that is directed towards developing the learner to become productive in teaching, paid employment and self-employment. Amoor and Udoh (2008) noted that business education plays a significant role in the economic development by providing knowledge and skills to the learners thereby enabling them to adequately impart knowledge into others, and handle sophisticated office technologies and information systems. The goal of business education is primarily to produce competent, skilful and dynamic business teachers, office administrators and businessmen and women that will effectively compete in the world of work (Odunaike and Amoda 2008).

Quality assurance refers to the planned and systematic activities implemented in a quality system so that quality requirements for a product or services will be fulfilled. Idialu (2007) described quality as standards of something as compared to other things. That is the degree of goodness or excellence. Quality assurance generally means all the procedures, processes and systems that support and develop the education (Kontio 2007). Lending credence to the aforementioned facts, ljaduola (2010a) submitted that 
the inadequate funding that has attended education generally has taken toll on vocational education of which business education is part and parcel. Adequate funding would determine moving forward to a large extent and the progress of this aspect of training in skills acquisition must be prioritized.

In another vein, ljaduola (2010b, 2011), among other things, suggested that professionals must be employed as tutors; and learning at 95\% determination must be practical and $5 \%$ theoretical in the curriculum of training. The instructors must be qualified professional trainers with vast experience and motivation traits in human resources development. This would enhance the rate of which learning and skills acquisition would take place by the learners.

At present, the calibre of students that graduate from business education, especially office education, according to Amoor (2008), have the problem of inadequate exposure to modern office technology, information systems and the rudiments of office administration. It is on this basis that this paper proposes to augment understanding about initiatives in Business Education in addition to its roles in quality assurance in higher institutions of learning.

Statement of the problems: The Business Education programme in higher institutions of learning has always been looked down upon. People prefer their children and wards to become lawyers, doctors, accountants etc. In spite of this problem, the government is not helping the situation by not funding the programme adequately. The researchers therefore became interested in assessing the quality of business education programme in selected higher institutions in Ogun State, Nigeria.

Purpose of the study: The main purpose of this study is to assess the quality of Business Education programme in higher institutions of learning in Ogun State. The specific objectives are:

To examine the funding of business education programme in the selected institutions in Ogun state.

- To investigate the competency of business education teachers in the institutions
- To examine the curriculum of business education programme in the institutions.

Hypotheses: The following three null hypotheses were posited to pilot the study.

$\mathrm{Ho}_{1}$ : There is no significant relationship between funding and quality of business education programme in higher institutions.

$\mathrm{Ho}_{2}$ : There is no significant relationship between qualified teachers and quality of business education programme in higher institutions.

$\mathrm{Ho}_{3}$ : There is no significant relationship between curriculum package and quality of business education programme in higher institutions.

\section{Method}

The descriptive research design was used in this study. Thirty (30) lecturers (at 10 lecturers per institution) drawn from three higher institutions offering Business Education as a programme participated in the study. The three institutions include: Tai Solarin University of Education, ljebuOde; Tai Solarin College of Education, Omu-ljebu; and Moshood Abiola Polytechnic, Abeokuta.

A-12 item questionnaire fashioned along the four points Likert-type was used for data collection. It was tagged; Quality of Business Education in Higher Institutions Questionnaire (QBEHIQ). The following corresponding scores were used as rating scale for the lecturers' responses: Strongly Agree (SA), 4 points; Agree (A),3 points; Disagree (D), 2 points; Strongly disagree (SD), 1 point. A construct validation of the questionnaire was done by two professional colleagues who are well versed in research. The research instrument also yielded a correlation coefficient of 0.87 following a test-retest treatment.

The three null hypotheses posited in the study were tested using the chi-square statistic at 0.05 level of confidence. The research instrument was personally administered to the respondents by the researchers for maximum retrieval. 


\section{RESULTS}

Table 1 - Responses to the assessment of Quality of Business Education Programme in Ogun State Higher Institutions

\begin{tabular}{|c|c|c|c|c|c|}
\hline $\mathbf{S} / \mathbf{N}$ & Details & SA & A & D & SD \\
\hline 1. & $\begin{array}{l}\text { The business education graduates from your } \\
\text { institution are well respected in the world of work }\end{array}$ & 12 & 13 & 3 & 2 \\
\hline 2. & $\begin{array}{l}\text { The business education programme in your } \\
\text { institution is well funded. }\end{array}$ & 5 & 3 & 10 & 12 \\
\hline 3. & $\begin{array}{l}\text { The use of typewriters is still very relevant in the } \\
\text { business education programme }\end{array}$ & 5 & 4 & 12 & 9 \\
\hline 4. & $\begin{array}{l}\text { There is adequate infrastructure in the business } \\
\text { education department of your institution }\end{array}$ & 2 & 5 & 14 & 9 \\
\hline 5. & $\begin{array}{l}\text { The appointment of the Heads in business education } \\
\text { in your institution is basically on merit }\end{array}$ & 8 & 10 & 7 & 5 \\
\hline 6. & $\begin{array}{l}\text { There are enough qualified teachers to handle the } \\
\text { business subjects in your institution. }\end{array}$ & 5 & 5 & 13 & 7 \\
\hline 7. & $\begin{array}{l}\text { There are competent hands to handle courses like } \\
\text { shorthand and typewriting in your institution }\end{array}$ & 3 & 4 & 15 & 8 \\
\hline 8. & $\begin{array}{l}\text { There is need to recruit more business education } \\
\text { teachers in your institution }\end{array}$ & 13 & 12 & 3 & 2 \\
\hline 9. & The image of business education programme is high & 3 & 5 & 15 & 7 \\
\hline 10. & $\begin{array}{l}\text { The curriculum of business education does not need } \\
\text { any review }\end{array}$ & 2 & 3 & 18 & 7 \\
\hline 11. & $\begin{array}{l}\text { The business education curriculum accommodates } \\
\text { the technological changes in the country }\end{array}$ & 3 & 4 & 13 & 10 \\
\hline 12. & $\begin{array}{l}\text { There is need to train more teachers in the business } \\
\text { education programme in order to ensure competency }\end{array}$ & 13 & 12 & 3 & 2 \\
\hline
\end{tabular}

$\mathrm{Ho}_{1}$ : There is no significant relationship between funding and quality of business education programme in higher institutions.

Table 2: Chi-square summary of test of the relationship between funding and quality of business education programme in higher institutions.

\begin{tabular}{|l|l|l|l|l|l|}
\hline Variation & Df & $X^{2}$ observed & $X^{2}$ critical & P & Remark \\
\hline $\begin{array}{l}\text { Funding } \\
\text { Quality of Business Education }\end{array}$ & 2 & 6.42 & 4.03 & 0.05 & S \\
\hline
\end{tabular}

In table 2, analysis of funding and quality of business education programme indicated a significant relationship. This is because the $X^{2}$ observed (6.42) is greater than the critical $X^{2}(4.03)$ at 0.05 level of significance and 2 degree of freedom. As a result, there is a significant relationship between funding and quality of business education programme in higher institutions. 
$\mathrm{Ho}_{2}$ : There is no significant relationship between qualified teachers and quality of business education programme in higher institutions.

Table 3: Chi-square summary of test of the relationship between qualified teachers and quality of business education in higher institutions.

\begin{tabular}{|c|c|c|c|c|c|}
\hline Variation & $\overline{D f}$ & $\begin{array}{l}\text { X2 } \\
\text { observed }\end{array}$ & $\begin{array}{l}\mathrm{X} 2 \\
\text { critical }\end{array}$ & $\mathrm{P}$ & $\begin{array}{l}\text { Remar } \\
\mathrm{k}\end{array}$ \\
\hline $\begin{array}{l}\text { Qualified } \\
\text { teachers } \\
\text { Quality of } \\
\text { Business } \\
\text { Education }\end{array}$ & 2 & 5.78 & 4.16 & 0.05 & $S$ \\
\hline
\end{tabular}

From the analysis displayed in table 3 , significant relationship was established between qualified teachers and quality of business education programme. This is predicated on the fact that the obtained $X^{2} 5.78$ is greater than the $X^{2}$ critical value of 4.16 at $\mathrm{df}=2$ and $P<0.05$. Hence, there is a significant relationship between qualified teachers and quality of business education programme in higher institutions.

$\mathrm{Ho}_{3}$ : There is no significant relationship between curriculum package and quality of business education programme in here institutions.

Table 4: Chi-square summary of test of the relationship between curriculum package and quality of business education programme in higher institutions.

\begin{tabular}{|l|l|l|l|l|l|}
\hline Variation & Df & $\begin{array}{l}\mathrm{X}^{2} \\
\text { observed }\end{array}$ & $\begin{array}{l}\mathrm{X}^{2} \\
\text { critical }\end{array}$ & $\mathrm{P}$ & Remark \\
\hline $\begin{array}{l}\text { Curriculum } \\
\text { Package } \\
\text { Quality of } \\
\text { Business } \\
\text { Education }\end{array}$ & 2 & 6.67 & 5.03 & 0.05 & $\mathrm{~S}$ \\
\hline
\end{tabular}

As shown in the analysis in table 4 , a $X^{2}$ value of 6.67 was obtained. This value is higher than the table value of 5.03 at 0.05 level of significance and $\mathrm{df}=2$. Thus, there is a significant relationship between the variables being considered. Consequently, the null hypothesis stated earlier is rejected.

SUMMARY OF FINDINGS: Test of hypothesis 1 shows that the first challenge militating against quality assurance in business education programme is poor funding and inadequate infrastructures which work against the goal of quality assurance.
- Another challenge is the politicisation of appointments of Heads of department of business education programme in educational institutions and escalation and erosion of academic culture in tertiary institutions.

- Shortage of teachers is another challenge facing quality assurance in business education as tested in hypothesis 2 . This was further confirmed by Quang and Shiyan (2007) who claimed that it is a well known fact that most of the higher institutions that offer business education programme suffer from shortage of teachers. As a result of this, teachers in business education with bias in Accounting or Marketing are found to be teaching courses like shorthand, typewriting which are secretarial based. This would consequently have effect on the skills, knowledge and competency of a university graduate in secretarial studies. In addition to this, the few teachers available are overloaded in the supervision of students projects and as a result discourages effective supervision of the projects.

- The use of Part-time teachers is also another problem facing quality assurance in business education. As a result of the shortage of teachers in business education, the use of part-time teachers is very common in the teaching of business education courses in most higher institutions of learning. This does not encourage effective teaching and learning as the commitment on the part of the teacher is very low. This consequently affects quality assurance in business education.

- Poor image of business education programme. Idialu (2007) stated that there is still a strong tendency towards white collar jobs as a result of low status associated with vocational education. He stressed further that most parents want their children to be medical doctors, lawyers, accountants etc. As a result, few people want to be teachers which consequently contributes to the problem of teacher education.

- Test of hypothesis 3 confirmed that Business Education curriculum is also another challenge facing quality assurance in business education. The business education curriculum does not reflect the technological development in the country. As a result, the secondary and higher institutions of learning 
still include subjects like shorthand and typewriting in their curriculum which is not relevant in the world of work.

\section{CONCLUSION}

The study concluded that there are a lot of problems facing the educational system in general and business education programme in particular. The relevant authorities have not shown any sign that they are committed to achieving quality in the educational sector. The ratio of teachers in business education programme to the students they teach is nothing to write home about, which does not allow quality teaching.

\section{RECOMMENDATIONS}

Government should expedite action on the legislative frame work for the proposed national commission for quality assurance as this would go a long way to harmonising and improving quality assurance at the different levels of education sector in Nigeria.

Government should also be ready to allocate substantial amount of money to education from the annual budget. This would greatly improve quality and standard of education in the country.

The curriculum of the business education programme should also be reviewed to reflect the current developmental and technological changes in the country.

Business Education teachers should also be recruited and should be allowed to go on regular training in order to be relevant.

The image of the business education programme should be improved by making the programme to be attractive and rewarding.

\section{REFERENCES}

Amoor S. S. (2008). Integrating the internet with the curriculum of office education programme in tertiary institutions in Nigeria. The information manager, 7(3), $42-49$
Amoor S. S. And Udoh A. A. (2008). The role of secretarial education in Nigeria economic development, Journal of Educational Research and Development, 3(1), 294298

Idialu E. E. (2007), Quality Assurance in the Teaching and Examination of Vocational and Technical Education in Nigeria, College Students Journal,4(2\&3), 10-16 http://findarticles.com/p.articles

ljaduola, K. O. (2010a). Quality management versus quality control: Latest development in Nigerian

University education. In M. A. Ogundipe, B. O. Olanisimi and O. E. Mabekoje (Eds.), Issues in university management and administration in Nigeria. Ibadan: Bayo Soye Publishers, pp. 128-151.

ljaduola K. O. (2010b). Higher education in Nigeria: Policies for adjustment, revitalization and expansion in the new millennium. Academic scholarship journal, 2(1), 49-64

ljaduola K. O. (2011). Prioritising education and skill development for human capital development in Africa. In T. A. Aladejana and B. O. Olanisimi (Eds), Human capital development in Africa. Ibadan: Codaat Publications, pp.15-26

Kontio J. (2007). International Quality up with the CDIO Initiative in Proceedings of the ICEE, Thelnternational conference on Engineering Education, Coimbra, Portugal. May 2007

Meisinger, M. and Wagner S. (2006). Integrating a model of analytical quality assurance into the $\mathrm{V}$-modell $\mathrm{XT}$, Foundations of Software Engineering. 24, 38-45.

Odunaike K. O. and Amoda M. B. (2008). The impact of Vocational Education on Business Education Students at Tai Solarin University of Education, ljebu-Ode, Ogun State, Journal of Business Education and Entrepreneurial Development (JOBEED), 1 (1) 81-95.

Qiang L. C. and Shiyan W. (2007). Factors affecting the quality of post-internship of higher vocationa Education. Computers in Human Behaviour, 2(4) 680683 